\title{
ナノマテリアルと化粧品の現状と将来
}

増永卓司

\section{Nanomaterials in Cosmetics-Present Situation and Future}

\author{
Takuji Masunaga \\ Japan Cosmetic Industry Association; Toranomon 45 MT bldg. 6F, 5-1-5 Toranomon, \\ Minato-ku, Tokyo 105-0001, Japan.
}

(Received July 27, 2013)

\begin{abstract}
Cosmetics are consumer products intended to contribute to increasing quality of life and designed for long-term daily use. Due to such features of cosmetics, they are required to ensure quality and safety at a high level, as well as to perform well, in response to consumers' demands. Recently, the technology associated with nanomaterials has progressed rapidly and has been applied to various products, including cosmetics. For example, nano-sized titanium dioxide has been formulated in sunscreen products in pursuit of improving its performance. As some researchers and media have expressed concerns about the safety of nanomaterials, a vague feeling of anxiety has been raised in society. In response to this concern, the Japan Cosmetic Industry Association (JCIA) has begun original research related to the safety assurance of nanomaterials formulated in cosmetics, to allow consumers to use cosmetics without such concerns. This paper describes the activities of the JCIA regarding safety research on nanomaterials, including a survey of the actual usage of nanomaterials in cosmetics, analysis of the existence of nanomaterials on the skin, and assessment of skin carcinogenicity of nano-sized titanium dioxide. It also describes the international status of safety assurance and regulation regarding nanomaterials in cosmetics.
\end{abstract}

Key words_-nanomaterial; cosmetic; safety; titanium dioxide; zinc oxide; regulation

\section{1.はじめに}

現在，ナノマテリアルには，統一的に確定した定 義はないものの，一般的には不溶性のもので，概ね 1-100 nm の大きさのものを指すことが多い. 本稿 では，ナノマテリアルが化粧品にどのように活用さ れているのかについて，サンスクリーン㓮を例とし て述べた後, 主に化粧品におけるナノマテリアルの 安全性に対する日本化粧品工業連合会（粧工連）の 取り組みを紹介し，最後に化粧品におけるナノマテ リアルの規制動向について触れる.

Conflict of Interest: Author belongs to the Japan Cosmetic Industry Association including the companies that make cosmetics containing nanomaterials such as titanium dioxide.

日本化粧品工業連合会（干105-0001 東京都港区虎ノ門 5-1-5 虎ノ門 45MT ビル 6 階)

e-mail: t-masunaga@kose.co.jp

本総説は, 日本薬学会第 133 年会シンポジウム S29103 で発表した内容を中心に記述したものである。

\section{2. ナノマテリアルと化粧品}

化粧品において, 最もナノマテリアルを活用して きたのはサンスクリーン剂であろう。サンスクリー ン剂は，紫外線を浴びることによる日光皮膚炎，あ るいはシミ，シワ等の予防を目的として使用されて いるものである。サンスクリーン剂の組成は，通常 の化粧品にも使われている水系, 油系成分などに加 えて，紫外線吸収剤や紫外線散乱剤といつた紫外線 を防御するための成分が含まれている。このうち, 紫外線散乱剂は無機金属粉体（酸化チタン, 酸化亜 鉛など）が使われており，サンスクリーン剂を皮膚 に塗布したときに，肌が白く見えたり，伸ばすとき に重たさを感じるなどの欠点につながっていた。こ れらの欠点を克服するために, 紫外線散乱剂の微粒 子化が検討され，その結果として得られた微粒子酸 化チタンを始めとするナノレベルの紫外線散乱剂 が，既に 20 年以上もの間にわたつて使用されてき ており，透明感が高く，サラッとした使用感で，日 常の乳液に近い感触を持つサンスクリーン剂が開発 
されてきた．すなわち，ナノマテリアルは，可視光 の波長より十分に小さな粒子径を持つため，可視光 の散乱が少なく透明感が高くなること，また，単位 重量当たりの個数も増え，効率よく紫外線防御効果 を得ることができるため，ナノマテリアルを配合し たサンスクリーン剤は，塗布しても白くならず，高 い紫外線防御効果を得ることができ，さらに紫外線 散乱剤の配合量が少ないため使用感をよくできると いつた特徽を有している.

\section{3. ナノマテリアルの使用実態調査研究}

2003 年頃から, ナノマテリアルの安全性を懸念 するような報告，報道があり，社会的にも漠然とし た不安が高まってきた。粧工連としては，このよう な状況の中，化粧品を使用する消費者の不安を払拭 し，化粧品の安全性をより確かなものにする目的 で，独自の研究プログラムの実施を開始した.

化粧品におけるナノマテリアルの安全性研究の基 礎として，まずは，化粧品におけるナノマテリアル の使用実態を明らかにすることとしたが，これは財 新エネルギー・産業技術総合開発機構（New Energy and Industrial Technology Development Organization; NEDO）の委託調查研究「ナノ原料を使用し た化粧品の安全性評価システムに関する基礎調査」 として実施した。その調查結果は，他誌に詳細が記 されているが, ${ }^{1)}$ 主な結果を，Fig. 1 に示した。粧 工連傘下の会員企業 741 社を対象に, 2005 年 1 月 31 日から 2 月 10 日の期間でアンケートを実施し, 478 社（64.5\%）から得られた回答を解析した結果 によると，ナノマテリアルを配合している化粧品会 社は 122 社（25.5\%）であり，使用されているナノ マテリアルは酸化チタンが最も多く，ついで酸化亜 鉛が多かった。また，ナノマテリアルを配合してい る化粧品は，日焼け止め（サンスクリーン剂）が最 も多く,ついでファンデーションであることが明ら かになった。

また，この NEDO 研究では, 安全性確認の状 況，ナノマテリアル（酸化チタン）の経皮吸収性に 係わる文献情報についても調査を行い，これらの結 果から，ナノマテリアルを配合した化粧品につい て，この時点で安全性上の問題はないことも示され ている．ただし，安全性研究の進歩に合わせた検証 が必要であることも述べられており，さらには，提 言として，国内の化粧品汎用成分に関して，経皮吸

収試験の成績を取得し，ナノマテリアルの安全性を 改めて検証する必要性が述べられている.

\section{4. 皮膚上における存在状態の解析手法開発}

毒性学上の一般論として， ある物質のリスクアセ スメントを実施するに当たつては，曝露状況を明ら かにする必要がある。NEDO 研究での提言である 経皮吸収試験の実施もその 1 つであるが，粧工連と しては，ナノマテリアルを皮膚に適用したときの， 皮膚上での存在状態を確認することにより, 経皮吸 収試験結果の科学的信頼性を高めることができると 考え，ナノ計測ワーキンググループを設置し，検討 を開始した，すなわち，本ワーキンググループの目 的は，皮膚に塗布されたナノマテリアルの皮膚上で の存在状態を把握する方法を開発することであった.

ナノ計測ワーキンググループにて議論を重ねた結 果，(1)マイカ基板上のナノマテリアルを原子間力顕 微鏡 (atomic force microscope; AFM) で観察する 方法，(2)擬似皮膚上のナノマテリアルを走査型電顕 (scanning electron microscope; SEM) で観察する方 法，(3)塗布膜のナノマテリアルを SEM で観察する 方法，(4)ナノマテリアルを塗布した皮膚を透過型電 顕（transmission electron microscope; TEM）で観 察する方法の 4 つの方法について検討することとし た. 検討の結果, Fig. 2 に示すように，いずれの方 法でもナノマテリアルの存在状態が解析可能である ことが示され，皮膚上での存在状態は，大部分の粒 子は凝集していること，100 $\mathrm{nm}$ 以下の粒子は極め てわずかであるがその存在は確認できること，経皮 吸収を示唆するような所見は認められなかったこと などが明らかになつた。なお，本検討は，ナノレべ ルの粒子の観察が可能か否かについて，定性的な解 析を行ったものであるが, 定量的解析は今後の課題 と考えられた。いずれにしても，これら各手法の特 徵を生かして, 皮膚上のナノマテリアルの存在状態 を把握することができ，それにより，経皮吸収試験 等の科学的信頼性を高めることができるものと考え た.

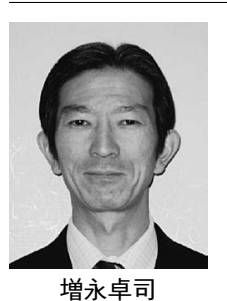

1986 年東京理科大学大学院薬学研究科 修了。同年小林コーセー (現・コー セー)に入社, 分析研究, 素材の開発・ 評価, 皮膚研究, 安全性研究に従事 し, 現在に至る。日本化粧品工業連合 会安全性部会委員. 医学博士. 


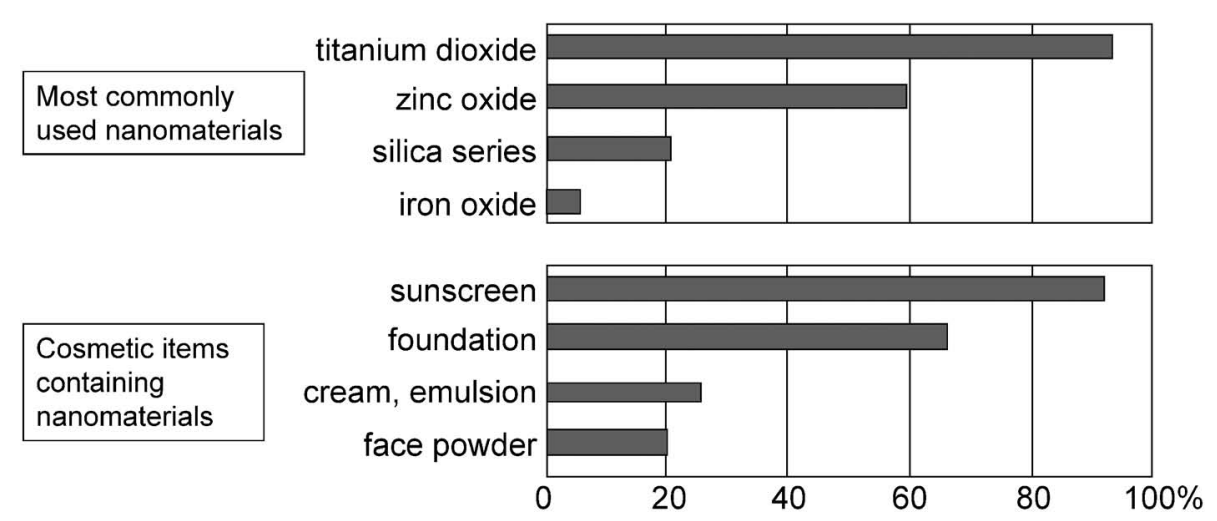

Fig. 1. Key Findings from the Survey of Actual Usage of Nanomaterials in Cosmetics

The most commonly used nanomaterial was titanium dioxide and the second most common was zinc oxide. Nanomaterials were mainly used in sunscreen and foundation.

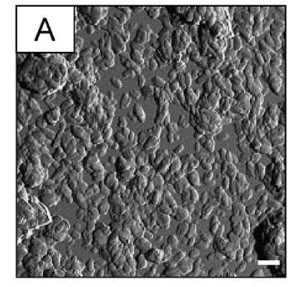

AFM

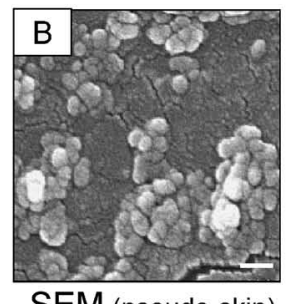

SEM (pseudo-skin)
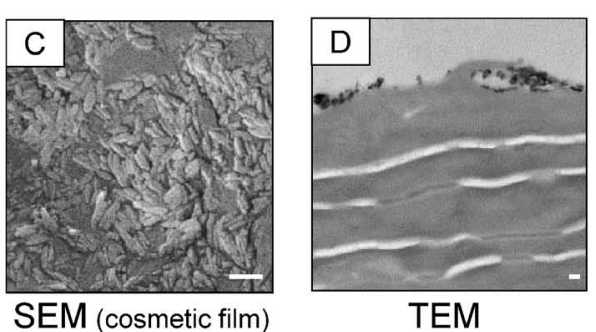

TEM

Fig. 2. Summary of the Analysis of the Existence of Nanomaterials on the Skin

A: Observation of nanomaterials by atomic force microscope (AFM); B: observation of nanomaterials on pseudo-skin by scanning electron microscope (SEM); C: observation of nanomaterials on cosmetic film by SEM; D: observation of nanomaterial-applied skin by transmission electron microscope (TEM) . Bars $=100 \mathrm{~nm}$.

なお，ナノマテリアル（酸化チタン）の経皮吸収 性試験については，この時期に開始された厚生労働 科学研究の分担研究の考え方が，粧工連の考え方と 一致するものであったことから，研究協力者として 参画することとした，その結果については，既に報 告されており，ナノマテリアルである酸化チタンが 経皮吸収されて, 定量限界以上に藏器に蓄積するこ とはなく, 毒性学的作用も起こらないことが示され ている. 2,3)

\section{5. その他の取り組み}

粧工連としては，ナノマテリアルの安全性に関し て，そのほかにも種々の取り組みを進めている.

その 1 つが酸化チタンの発がん性に係わる研究で ある. 酸化チタンについては, 経皮での発がん性に ついて懸念されたこともあったが，消費者の安全性 を確保するために，中期の試験法として知られてい る二段階発がん性試験を実施した，その結果，陽性 物質では腫瘤の発生が認められる試験系において, 酸化チタンには, 皮膚発がんに対するプロモーショ
ン作用は認められなかった. ${ }^{4)}$ なお，時期を同じく して, 他の研究グループからも同様の結論が報告さ れている.5)

また，粧工連では，ナノマテリアルに関する情報 収集・発信も行っており，それを目的としたナノ安 全性情報ワーキンググループも設置している。 ま た, 欧米の化粧品工業会との協力, 日米欧加の 4 極 の化粧品規制当局と業界から構成される化粧品規制 協力国際会議 (International Cooperation on Cosmetics Regulation; ICCR) への参加とサポート, 各 研究機関・大学が実施するナノマテリアルに関する 安全性研究への協力, 各種の研究会・班会議への参 加，行政との意見交換・情報提供，粧工連のホーム ページ（http://www.jcia.org/）を通した情報の公 開などの活動も進めている.

\section{6. 化粧品に係わるナノマテリアルの規制等}

現在, 国内外を含めて，化粧品にナノマテリアル を配合することを禁止している規制はないものと認 識している. 
欧州においては, 2013 年 7 月 11 日から, 新たな 化粧品規制が施行された. ${ }^{6)}$ その中ではナノマテリ アルに係わる項目も含まれている。この化粧品規制 では，ナノマテリアルを「不溶性であるか生体内残 留性があり，意図的に製造された材料で，一次元以 上の外面あるいは内部構造が 1-100 nm のスケール であるもの」と定義しており，このようなナノマテ リアルを含む化粧品については，成分名の後に (nano) と表示しなくてはならない. また，ナノマ テリアルを含有する化粧品は, 発売の 6 力月前に, 欧州委員会へ届け出る必要がある（ただし，ANNEX に収載されている UV filter 等のナノマテリア ルについてはこの規定から除外されている).

ナノに係わる表示については, 議論がある. 上述 の欧州でのナノの表示は，消費者への情報提供の観 点から行われるものと考えられ, 台湾, 韓国, 二 ユージーランドなどで, 同様の動きがある。一方 で, メルボルン大学の Wright 教授は, 「ナノ不使 用」のラベルについて適切ではないと指摘してお り，その理由は，「ナノマテリアルには様々な種類 があるにもかかわらず，すべてのナノマテリアルが 一律に健康に悪いものであると消費者に誤つた解釈

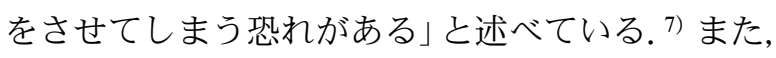
オーストラリア広告機構は, 消費者の懸念をいたず らに㮼るだけであるとして，サンスクリーン剂にお ける「ナノ不使用」のラベルを削除するように指示 した. ${ }^{8)}$

その他の主な動向としては, 以下のようなものが 挙げられる. 米国皮膚科学会が, ナノ材料を用いた 日焼け止めに対して，「日焼け止めは紫外線による 健康被害から身を守るための，効果的で安全な手段

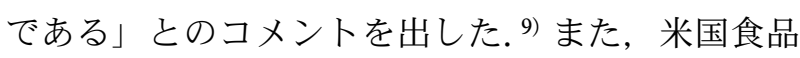
医薬品局 (U.S. Food and Drug Administration; FDA）は「ナノテクノロジーを用いた化粧品のガ イダンス案」を，欧州の消費者安全科学委員会 (Scientific Committee on Consumer Safety; SCCS) は 「化粧品中のナノマテリアルに関する安全性評価ガ イダンス」を，それぞれ発表した. ${ }^{10,11) ま た ， ~}$

SCCS は, 2012 年 12 月に, サンスクリーン剤への ナノ酸化亜鉛の配合について, 純度, 結晶型などの 条件がついているものの，ヒトへの有害作用をもた らすリスクはないと結論した. ${ }^{12)}$ これは当局がナノ マテリアルについて「安全」と結論を出したもので
あり，その意義は大きいと考えられる.

\section{7. 今後の課題}

ナノマテリアルについては, 今後解決すべき課題 が残っている. 最初にも述べたが，ナノマテリアル に関しての統一的な定義も定まっておらず，また測 定法に関する問題もある。特に化粧品の最終製剤中 での測定法については，ICCRの中でも「現時点 で，適切に測定する手法はない」とされている.

また，粧工連としても，欧米を始めとした国際的 な連携，ナノマテリアルに関する情報発信の強化,

リスクコミュニケーションの必要性など，消費者に 安心して化粧品を使用して頂く上でも，取り組まな くてはならない課題は多い.これらの課題を $1 つ 1$ つ解決していき，消費者の安全性を確保することが 必要であると考えている.

謝辞本総説は，日本化粧品工業連合会安全性 部会ナノ計測ワーキンググループ及びナノ安全性情 報ワーキンググループとしての活動を中心にまとめ たものである．各ワーキンググループ参加各位に深 謝致します。

ナノ計測ワーキンググループ：エスティ・ロー ダー株式会社, 花王株式会社, 株式会社カネボウ化 粧品, 株式会社コーセー, 株式会社資生堂, 株式会 社ナリス化粧品, 日光ケミカルズ株式会社, 日本ア ムウェイ合同会社, 日本メナード化粧品株式会社, 日本ロレアル株式会社, プロクター・アンド・ギャ ンブル・ジャパン株式会社, ポーラ化成工業株式会 社, ライオン株式会社, 株式会社マンダム, ロート 製薬株式会社，日本化粧品工業連合会（事務局）

ナノ安全性情報ワーキンググループ: 花王株式会 社, 株式会社力ネボウ化粧品, 株式会社コーセー, 株式会社資生堂, 日本ロレアル株式会社, プロク ター・アンド・ギャンブル・ジャパン株式会社, ポーラ化成工業株式会社

\section{REFERENCES}

1) Hatakeyama Y., J. Jan. Cosmet. Sci. Soc., 29, 225-231 (2005).

2) Ikarashi Y., Takita Y., Obama T., Uchino. T., Nishimura T., Abstracts of Papers, the 36th Annual Meeting of the Japanese Society of Toxicology, Morioka, July 2009, p. S194. 
3) Ikarashi Y., Aiba Y., Uchino T., Nishimura T., Abstracts of Papers, the 37th Annual Meeting of the Japanese Society of Toxicology, Ginowan, June 2010, p. S171.

4) Furukawa F., Doi Y., Suguro M., Morita O., Kuwahara H., Masunaga T., Hatakeyama Y., Mori F., Food Chem. Toxicol., 49, 744-749 (2011).

5) Xu J., Sagawa Y., Futakuchi M., Fukamachi K., Alexander D. B., Furukawa F., Ikarashi Y., Uchino T., Nishimura T., Morita A., Suzui M., Tsuda H., Food Chem. Toxicol., 49, 1298-1302 (2011).

6) Regulation (EC) No $1223 / 2009$ of the European Parliament and of the Council of 30 November 2009 on cosmetic products: 〈http:// eur-lex.europa.eu/JOHtml.do?uri=OJ:L:2009 :342:SOM:EN:HTML $\rangle$, cited 29 August, 2013.

7) Wright P., “Warning: contains nanotech.": 〈http://www.cosmosmagazine.com/opinion/ warning-contains-nanotech/, COSMOS Web, cited 29 August, 2013.

8) Complaints Resolution Panel Determination: 〈http://www.tgacrp.com.au/index.cfm?page ID $=13 \&$ special $=$ complaint_single\&complaint
ID =1691 $\rangle$, cited 29 August, 2013.

9) American Academy of Dermatology. "Sunscreens remain safe, effective form of sun protection.": 〈http://www.aad.org/stories-andnews / news-releases / sunscreens-remain-safeeffective-form-of-sun-protection $\rangle$, cited 29 August, 2013.

10) U.S. Department of Health and Human Services, Food and Drug Administration. "Guidance for Industry: Safety of Nanomaterials in Cosmetic Products.": 〈http://www.fda.gov/ downloads / Cosmetics / GuidanceCompliance RegulatoryInformation / GuidanceDocuments /UCM300932.pdf $\rangle$, cited 29 August, 2013.

11) Scientific Committee on Consumer Safety. "Guidance on the Safety Assessment of Nanomaterials in Cosmetics.": 〈http://ec.europa. eu/health/scientific_committees / consumer safety/docs/sccs_s_005.pdf $\rangle$, cited 29 August, 2013.

12) Scientific Committee on Consumer Safety. "Opinion on Zinc Oxide (nano form).": 〈http://ec.europa.eu/health/scientific_committees/consumer_safety/docs/sccs_o_103. pdf $\rangle$, cited 29 August, 2013. 